\title{
Sciendo
}

DOI: $10.1515 / \mathrm{aa}-2018-0004$

\section{Romancing the crucifixion in biblical rewritings by Phillip Pullman and Colm Tóibín}

Ewa Rychter

Ewa Rychter holds a doctorate degree in literary theory and a degree in biblical studies. She is the author of a monograph (Un)Saying the Other (Frankfurt 2004), editor of a volume of essays on post-theory (in Polish, Po(granicza) teorii, Walbrzych 2010), editor of Beyond 2000: The Recent Novel in English (Walbrzych 2011), and co-editor of the scholarly journal Orbis Linguarum. She is also the author of more than 30 articles on literary theory, contemporary philosophy, the Bible in contemporary culture and contemporary British fiction. She is a senior lecturer at The Angelus Silesius University of Applied Sciences, Walbrzych, Poland.

\begin{abstract}
:
This paper focuses on how the romance mode is used to re-narrativize the trauma of Jesus's crucifixion in two contemporary biblical rewritings: Pullman's The Good Man Jesus and the Scoundrel Christ (2010) and Tóibin's The Testament of Mary (2012). Reflecting on the process of the composition of the Bible, these novels resort to romance in order to invite a critical reflection on different narrativizations of the traumatic event, dependent as they are on both conservative and more subversive effects of romance. As some characters rely on the strategies of traditional spiritual romance in order to alleviate their pain, others cynically resort to a dualistic vision to establish and consolidate power, and still others make use of the excess and disarticulation of romance to do justice to the absolute horror of the event, the novels draw attention both to the comforting and subversive function of Christian scripture. Adding a metafictional dimension to the narrative of crucifixion, the novels expose the way in which religious scriptures can become ideological instruments, and signal the potentially dangerous effects of the renewed significance of religion today.
\end{abstract}

Of the many traumatic events narrated in the Christian Bible, the crucifixion of Jesus is perhaps the most memorable and the most important from the point of view of Western culture. For David Carr, the author of Holy Resilience: The Bible's Traumatic Origins, the crucifixion is "Christianity's founding trauma" (2014, p.156), its critical core and symbolic basis, framed by the broader trauma-generated paradigm of the whole Bible (Carr avers that the "Jewish and Christian scriptures arose out of and speak to catastrophic human trauma" [2014, p.5]).

Carr's conceptualization of the crucifixion as trauma emphasizes two, contradictory aspects of this central Christian event. While the earliest crucifixion narrative in the gospel of Mark “describes Jesus' end in a relatively raw, unprocessed way" (Carr, 2014, p. 160), leaving 
the trauma of the event unworked through and showing it as an experience "not yet fully owned" (Caruth, 1991, p. 110), other accounts try to come to terms with the horror of Jesus's crucifixion, reinterpreting it through the lens of older scriptural narratives. ${ }^{i}$ On the one hand, the trauma of the crucifixion is perceived as successfully worked through, a victory and a defining moment in a teleological narrative of redemption, a feat which supplies the Christian community with a new understanding of itself and makes it uniquely resilient in the future. On the other hand, crucifixion persists as something that can be neither effectively represented, nor fully understood or assimilated into words and images. "Despite the progressive addition of resurrection traditions to the story of Jesus," Carr observes, "the writings of the New Testament still return again and again to the crucifixion. So much focuses on processing Jesus' painful, humiliating, community-shattering death" (2014, p. 249). Although Jesus's crucifixion seems to be an effectively semiotized trauma, it continues to vex Christians and call for ever new symbolizations. Also - as the "Christian institutionalisation of trauma" (ibid., p. 246) crucifixion continues to be a source of suffering in post-biblical times, opening new wounds and triggering new traumas. ${ }^{\text {ii }}$

One could rephrase this ambivalence residual in Carr's discussion of the crucifixion-astrauma and say that in the Bible, Jesus's death is simultaneously part of the story with a resolution and happy ending (qua resurrection and redemption), and an element that will not be contained in such story, or completely accounted for. On the one hand, it is framed by what Northrop Frye calls the U-shaped structure of the Bible, (i.e., a story of a descent into catastrophe, followed by rescue and ascent to a state of well-being $\left.{ }^{\mathrm{iii}}\right)$. On the other hand, it disturbs such an upbeat plot, resurfacing time and again in Christianity and echoing with other traumas introduced through the redeployed older trauma texts. As Carr puts it, "the abiding trauma of Jesus' crucifixion" shows "its lingering force" in the ever renewed "process of trying to deal with the reality of Jesus' death" (2014, p. 232).

It is this ambivalence around Jesus's crucifixion that Philip Pullman's The Good Man Jesus and the Scoundrel Christ (2010) and Colm Tóibín's The Testament of Mary (2012) explore. This paper will claim that, while showing the crucifixion as an important event in Jesus's life and ministry, the novels approach it through different - indeed, contradictory strategies of romance, a mode ${ }^{\mathrm{iv}}$ which is remarkably well suited to deal with the paradoxes of trauma (Ganteau and Onega, 2013; Heng, 2003, p. 2). The novels rely both on romance's more traditional, euphoric from, consistent with Frye's U-shaped plot, and on the darker, entropic forms of romance, with their insistence on disarticulation, impurity, dilation and excess. The 
former type of romance corresponds with the victorious narrative of redemption in the Bible, and the latter with those biblical passages where the crucifixion remains raw and unprocessed.

Significantly, Pullman's and Tóibín's romancing of the crucifixion is not meant to merely revisit and foreground the Bible's dual approach to Jesus's death. And neither does it simply rehash the Bible's romance-related supernaturalism and spectacularity, nor only test the limits of what Erich Auerbach identified as the gospel formula of realism, in which the noble coexists with the low. As instances of "scriptural metafiction" (Mączyńska, 2015, p. 4) that rewrite the Bible, simultaneously reflecting on the mechanisms and strategies of the composition of scripture, the novels invite a critical insight into different romance-based narrativizations of the traumatic event. Either contrasting a romanced version of Jesus's life and crucifixion with approaches couched in the realistic mode, or stacking up a variant of a sacred (euphoric) romance against a more subversive (entropic) romance, the biblical rewritings by Pullman and Tóibín bring to light and examine different ideological groundings of crucifixion narratives, as well as draw attention to their lingering traumatic effect, palpable long after the Christian Bible acquired the status of a closed book. Admittedly, as rewritings of the Bible, i.e. as texts that return to what remains a disturbing and haunting element of culture, the novels themselves testify to the lingering force of biblical trauma, repeating and rearticulating the infallibly horrifying story. The novels propose a metafictionally slanted reconstruction of "the traumatic formation of the scripture" (Carr, 2014, p. 245), in which the "Christian institutionalisation of trauma" (ibid., p. 246) is scrutinized and the limits of coming to terms with trauma are shown. Additionally, relying on romance as a mode which tries to work through and alleviate current cultural anxieties (Heng, 2003, p. 14), the rewritings articulate the present sense of insecurity generated by the return of religion, its deprivatization and new visibility.

\section{Romance, the Christian Bible, trauma}

Romance and the Bible have already been drawn together by literary and biblical scholars employing romance either to study the Bible's general framework or to analyse its specific elements. Such romance-based readings not only prove that the Bible should not be seen as impervious to romance but also provide a useful vantage point from which biblical rewritings can be perceived.

One approach to the overlap between romance and the Bible focuses on the influence on and/or appropriation into biblical narratives of various elements of romance understood as a genre. Scholars such as R.I. Pervo and Alexander Loveday linked ancient Greek romance to the Acts, and listed generic similarities these writings share (e.g. the structuring function of the sea 
voyage, the schematic patterns of movement, the presence of adventures, wit and humour). Even though Pervo's approach fails to prove that Acts is an instance of a Greek romance "properly defined" (Witherington, 1998, p. 377), ${ }^{\mathrm{v}}$ it cannot but be lauded for the fact that it draws attention to those aspects of Acts that "have been underappreciated by scholars" (ibid., p. 378) - namely, humour, wit, irony and pathos. The fact that there is a loose overlap between the Christian Bible and romance, rather than a faithful application of generic romance features, can be treated as a useful background (or reference point) for the understanding of the biblical rewritings by Pullman and Tóibín. Their loose linking of the Bible with historically grounded romance genres has the advantage of foregrounding those issues or problems of the hypotext that otherwise go unnoticed or underappreciated. As scriptural metafictions, the rewritings make use of their romance-based revisions to critically explore the consoling, verisimilitudeshunning character of the Christian Bible.

Another approach to the relationship between the Bible and romance can be found in Pierre Vitoux, who re-reads Northrop Frye's classification of modes in Anatomy of Criticism. For Vitoux, romance is irreducible to an autonomous mode, but emerges "in reaction against the specific norms of the world of the other modes" (2007, p. 391). As a reactive mode, romance is correlated with various determinations operating within the mythic, high mimetic, low mimetic and ironic modes. In the case of the mythic (the category to which the Hebrew Bible belongs in Frye's scheme), romance appears as a response to the self-containment and transcendence of the mythic, divine world. ${ }^{\mathrm{vi}}$ Discussing the way romance appears within the high mimetic parts of the Christian Bible (the parts focusing on the apostles and their mission), Vitoux observes that it relies on the romance motif of quest and on the constructive, optimistic mission of human heroes, which is a reaction against the catastrophic spirit common to tragedy and the old epic. Seen in the light of Vitoux's reasoning, the act of romancing the trauma of crucifixion in the contemporary biblical rewritings by Pullman and Tóibín (i.e., their romancebased transformation of the tragic/traumatic) turn out to be rooted in (and metafictionally capitalize on) the actual processes that shaped the Bible. Also, Vitoux's contention about romance as a response to the ironic mode - namely, that romance partakes in ironic detachment and self-deprecation yet, simultaneously, tries to expose and cleanse evil - will be a useful framing idea for my reading of the way Pullman's and Tóibín's scriptural metafictions debunk the falsehood and desire for power which inform ideological uses of scripture.

Admittedly, described as a reactive mode - i.e., a set of flexible, trans-generic strategies which interact with other literary forms - romance can be seen as an impure, excessive and contradictory form. For Patricia Parker, romance occupies the realm of suspension, uncertainty 
and error. It thrives in the twilight space of chiaroscuro, where delay and deviation can dominate, and where "the subversion of the teleological model of meaning" (Parker 1979, p. 10 ) is only sometimes replaced with the revelation of truth. Romance is a form which "simultaneously quests for and postpones a particular end, objective or object [...]" (Parker 1979, p. 4), a form which "involves the dilation of a threshold" (Parker, 1979, p. 5) that separates questing heroes from their aims. Diane Elam conceptualizes romance as excessive and hybrid, i.e. as impossible to contain within the scope of one genre/convention or one historical time. A critical and reflective mode, romance often accompanies realism and disturbs its complacencies or efforts to make the represented world intelligible and manageable. "We are never quite sure," Elam observes, "what romance may mean or how it may mean" (1992, p. 7). Bringing together N. Frye's, F. Jameson's, J. Radway's and R. Coward's conceptualizations of romance, Elam claims that romance can be both conservative/reactionary and emancipatory/transformative. It can be built both into anarchic (radical, utopian) and oppressive discourses (of colonialism, imperialism, patriarchy, bourgeoisie, consumerism). Romance's contradictoriness, excessiveness and heterogeneity are exploited by Pullman and Tóibín to re-vision the crucifixion, to revise the Christian Bible, as well as to metafictionally reflect on the ideological construction and use of scripture.

Importantly, the impurity, flexibility and contradictoriness of the romance mode is what Jean-Michel Ganteau and Susana Onega make the basis of their pioneering work in the field of romance-related trauma studies. Romance's repetitiveness, spectacularity, mystery and miraculousness can be employed either to work through trauma and achieve healing, or to rehearse the past enigma/wound and probe the limits of the representable. Ganteau and Onega claim that insofar as trauma cannot be adequately represented in realistic narrative, trauma fiction "seem $[\mathrm{s}]$ to evince a formal affinity with the poetics of romance, $[\ldots]$ solicited whenever realism fails to evoke limit-case situations" (2013, p. 1-2). As a mode which on the one hand "collaborates with [...] or dynamises" realism (Ganteau, Onega, 2013, p. 5), and on the other hand, disrupts mimetic modes, romance is conversant not only with attempts to overcome trauma and give adequate/final shape to the past but also with the realism-resistant character of traumatic experience. The "paroxystic expression of the irrational" in romance (ibid., p. 3), its subversion of verisimilitude, and its excessive expressiveness dilate realism and open the narrative for the non-mimetic. Consequently, romanced trauma is an exercise in dealing with an unforgettable past which, however, is impossible to fully remember. As Ganteau and Onega cogently put it, "romance is a monstrous mode that performs the groping and privation inherent in the literary presentation of trauma in the efficiently performative drive of traumatic realism 
and which allows for some asymptotic evocation of trauma, always moving towards it and rarely managing to spell it, remaining on the verge of, or around, the other of trauma $[\ldots]$ " (ibid., p.10).

In Pullman's and Tóibín's rewritings, Ganteau's and Onega's two streaks of romance constitute two different approaches to the trauma of crucifixion; concomitantly, they construct two different vantage points - two attitudes to romancing the crucifixion - from which Jesus's life is read. The novels romance trauma both in a darker, disarticulating, subversive way, and in a conservative, sentimental and comforting manner. On the one hand, they emphasize the impossibility of adequately representing trauma; on the other hand, they accentuate the healing effects and the romance-proffered certainty of the narrated catastrophe. The juxtaposition of the two ways of romancing the crucifixion draws attention to an important tension within the Bible - the tension between the discourse of a protracted certainty of triumph (disconcertingly open to ideological appropriation), and the less conspicuous discourse of "the abiding trauma" (Carr, 2014, p. 232) and disturbing absence of complete knowledge.

\section{Philip Pullman, The Good Man Jesus and the Scoundrel Christ (2010)}

The central theme and an organizing principle ${ }^{\text {vii }}$ of Pullman's rewriting is the motif of Jesus and his twin brother, a motif not unknown in apocryphal biblical literature. ${ }^{\text {viii }}$ The motif can be treated as a governing metaphor of the overlap and disparity between different ways of dealing with the shock of crucifixion and death. Until the crucifixion, both brothers employ a version of a euphoric romance to structure their experience. Later, the trauma of (approaching) death forces both Jesus and Christ to reconsider the romances they hitherto constructed and confront the darker dimension of the way they chose to give shape to their lives. Though the quality of darkness they discern is different, the perplexing sense of its unknowability, the frustrating deferral of its unveiling, characterizes both Jesus's and Christ's trauma-induced romances.

In the novel, Christ is presented as a sickly, quiet and studious child, always keen on winning the admiration of adults, always ready to perform a miracle to save from punishment his undisciplined, boisterous and passionate twin brother. ${ }^{\text {ix }}$ Whatever mischief Jesus performs, his brother sets everything right, restores lost order, removes the effects of harm, transfigures the bad into good. Later, Christ develops a more intellectual variety of this basic romance strategy of the miraculous transformation, which consists in revealing a transcendental horizon, a symbolic meaning behind Jesus's worldly (and naughty) actions. Thus, for example, using his phenomenal knowledge of the Hebrew Bible, Christ reads a deep, spiritual meaning into Jesus's 
infantile prank of daubing mud on the temple wall to write his name there. This two-pronged romancing of Jesus - framing him with supernaturalism and transfiguring his imperfections continues until (and actually, after) his crucifixion, becoming related to the project of documenting Jesus's teaching and works, which quickly becomes a project of spiritualizing, de-realizing, idealizing and intensifying Jesus. After Jesus's baptism, Christ starts to transforms the down-to-earth quality of his brother's life into a story of a divine intervention in human affairs, a story full of signs, portents and miracles. A believer in the "importance of dramatic events" (Pullman, 2010, p. 171), Christ diminishes the mimetic or realistic dimension of his story and intensifies the symbolic potential of his narrative of Jesus. The dove in a tree at the baptism scene becomes a sign of election, accompanied by a voice from heaven. Jesus's expectation of the Kingdom becomes "a test for us" (ibid., p. 42), while the simple fact of sharing food becomes a story of the miracle of the multiplication of bread.

When Christ is approached by the Stranger and asked to keep a written record of Jesus's words, he learns that unlike a historian, he should write "of things as they should have been" (ibid., p. 99) and reveal their deeper, non-literal truth. Jesus's message must be transcendentalized, its passion must be redirected from the ethical and humane towards the theological and abstract, its elements must be organized into clearly separated oppositions. In typical romance fashion, Christ reaches beyond what is available to a reporter or realistic writer, and, rather than merely recording it, he gives events a deeper meaning. The Stranger instructs Christ about the nature of the world, which turns out to be bipolar, rooted in a struggle between good and evil, in a manner characteristic to the traditional, sacred romance ("There is time, and there is what is beyond time. There is darkness, and there is light" [ibid., p.58]). Asked to "add to the outward and visible events their inward and spiritual significance" (Pullman 2010, p. 124), Christ becomes bolder in his countervailing of realism with romance-based spiritualization and supernaturalism. Finally, pressed by the Stranger, Christ betrays Jesus (i.e. plays the Judas role), and poses as the resurrected Jesus. In an ironic (literalized) Gothic twist to the sacred romance, he "becomes" the spectral Jesus, both enacting the ultimate romance transfiguration/redemption of the mundane (mortality), and inscribing his narrative with the traumatic, unrepresentable fact of death. Afterwards, acting on his knowledge that people "like mysteries and [...] adore miracles" (ibid., p. 226), Christ establishes the Eucharist as a disturbing but evocative way of representing and remembering the trauma of the crucifixion.

In his actions and in the scripture he composes, Christ transforms his own trauma of confronting the crucifixion he himself brought about (as well as the trauma of his own survival) through rewriting Jesus's life and death as a sacred romance of redemption. Christ consciously 
romances Jesus's crucifixion, transforming its "shock" (ibid., p.229) into a mere critical point on a U-shaped plot-line, a point followed by the resurrection as the suspension of death as a law of nature and the ascension towards the triumph over evil. At his hands, the crucifixion becomes something Jesus knew about in advance and met willingly, and acquires "a far more resonant meaning, and one that would open depths of mystery [...]" (ibid., p.243).

However, the euphoric character of Christ's romance is counterbalanced (if not questioned) by the darker dimension of the larger, romance-related framework in the novel. Christ has to confront not only the trauma of the crucifixion of his brother but also the devastating realization that the romance-based transformation of Jesus's narrative will be used first to establish and then to expand power over "credulous" (ibid., p. 225), miracle-thirsty people. As the Stranger explains, the story constructed by Christ, the story climaxing with the miracle of the resurrection, will attract believers and distract them from a desire to transform their own lives for the better. "It would be unfortunate," the Stranger avers, "if people came to read some of his [Jesus's] sayings as a call to political action; as we know they are nothing of the sort" (ibid., p. 241). The Stranger expects Christ's romance to suppress what Jameson described as the transformative, resistance-enhancing function of romance. Christ's scripture is to support the Church's ideology and secure and reproduce the power of its hegemonic discourse.

Although Jesus is very sceptical about miracles (ibid., p. 41) and rejects Christ's spiritualizing, realism-evading attitude, he also relies on euphoric romance strategies to construct his teaching. His message of the coming Kingdom, of prayers answered, of suffering redeemed and evil defeated is basically romance as utopian fantasy, i.e., a vision of the fulfilment that will deliver humans from the anxieties of reality but will still contain this reality (cf. Frye 1957, p. 193). However, in the Garden of Gethsemane, a place associated with Jesus's preparation for his death, Jesus replaces this utopian vision with a darker insight, more conversant with his realization that the posited end (God's Kingdom) will not be achieved. Jesus chooses to approach his own death in a manner similar to what Parker describes as romance ending with the abyss, i.e., through the dilation of a threshold and pensive confrontation of darkness. In Gethsemane, Jesus talks of the Kingdom as something infinitely deferred: "I can see us waiting, and waiting and waiting..." (Pullman 2010, p. 196). This "subversion of the teleological model of meaning" (Parker, 1979, p. 10), which characterizes the romance of dilation and which dominates Jesus's final vision, avoids the tragic mood and, instead, concentrates on the uncertainty of knowledge, on baffling mysteries. Thus, Jesus asks whether "enigmas and riddles" (Pullman 2010, p.194) of various phenomena in the world are 
difficult to read but "full of [...God's] words", or whether they are actually "blank and meaningless" (ibid., p. 195). He does not doubt the possibility of healing but wants to know why it does not arrive (ibid., p.196).

Jesus's Gethsemane monologue is an entropic romance, expressing both anxiety about the uncertainty of redemption and a deep desire for it. It gives shape to the traumatizing look into the abyss of the divine absence, speaking in an intense, excessive language, still praying to what is possibly absent. ${ }^{\mathrm{x}}$ The approaching catastrophe of death cannot but be seen through the prism of the traumatic realization that God is "in the silence" (ibid., p.195). Perceived through the uncertainty of redemption, death can only make this absence achingly visible.

Interestingly, although different in their final choice of ways to romance traumas, Christ and Jesus share the trauma-triggered awareness that what they considered their mission (quest) contains a dark, only half-comprehended core. Initially, Jesus draws on the romance of restoration of Edenic conditions, yet later suspects that God - on whom the romance relied may not exist. Having confronted the enigma of God's indifference/non-existence, he questions his optimistic vision and grapples with the unknowable. Simultaneously, Christ fails to discover the identity of the Stranger, a mysteriously powerful, all-knowing and manipulative character. As the Stranger openly denies being Satan, Christ is left to speculate that he is probably God, which makes the romance motif of "the Other" finally revealing his name deeply unsettling. Instead of reaffirming the redemptive aspect of the Other as providential mystery, the Stranger proves something of a gothic villain, whose dark motivations - though not entirely clear - frame the story with an air of cosmic horror and install a traumatizing potential inside it. Christ realizes that his idealization-based narrative of miracles, supernatural power and the unveiling of truth in Jesus's life and death is actually the Stranger's ruse meant to keep people under control and secure power of one group, and a cover-up for future horrifying crimes and perversions (described in detail by Jesus in his Gethsemane monologue).

Pullman's metafictional exploration of the way scripture is produced and used does more than only draw attention to the ideological hijacking of the consoling potential of euphoric romance. It also foregrounds the way the emancipatory, revolutionary edge of the Bible's romance-related structure is perverted and lost. Voiced in Jesus's Gethsemane prayer for the Church to be based on forgiveness, love, modesty, equality and openness, the transformative dimension of Jesus's romance-like vision of the Kingdom is shown as suppressed in the scripture composed by Christ. The oppressed are not to be empowered by Jesus's teachings, and its subversive potential is to be effaced. Thus, Pullman's biblical rewriting shows that the optimistic and healing quality of the biblical romance is disturbed with a darker, subversive 
tone, a tone the novel borrows from Gothic convention. It is not coincidental that Christ - the eponymous "scoundrel" - plays the role of the gothic hero-villain, endowed with the potential for both great accomplishments and dreadful deeds. In exposing the evil potential of scripture, Pullman's romance adopts an ironic form identified by Vitoux: while romancing the crucifixion, it maintains a self-deprecating distance from the triumphalism of the religious narrative of salvation, and reveals religion's rootedness in a desire for domination and its traumatizing potential.

\section{Colm Tóibín, The Testament of Mary (2012)}

While Pullman's biblical rewriting uses the darker type of romance sparingly, allowing it to discretely seep into the dominant, euphoric romance and disturb its optimism, Tóibín makes dark romance the backbone of his revision, leaving just a little room for sacred romance, showing its construction and predicting its ultimate triumph in the future. The Testament of Mary narrates the biblical events from the point of view of Jesus's mother, who - facing her own, impending death - wants to tell the truth "or else everything that happened will become a sweet story that will grow poisonous as bright berries that hang low on trees" (Tóibín, 2012, p. 86). Mary tells her subversive, terror-laden story to impede the transformation of the crucifixion (and everything that preceded and followed it) into a story of salvation and triumph over evil and darkness. She counters the budding euphoric romance with her dark, Gothic-like romance, in which darkness and evil prove to be ineradicable sources of anxiety and fear.

Structured like "torturous, fragmented narratives" in the Gothic tradition (Botting, 1996, p. 2) and delivered in a paroxystic discourse that struggles with the incommunicable, Mary's story attempts to recount the series of deeply disturbing, frightening and barely comprehensible events that climaxed in Jesus's crucifixion. Mary describes Jesus's mission - his gathering of followers, his performing of miracles, his demeanour - as something for which she "did not have words" (Tóibín, 2012, p. 52). There is something unhinged, mad and excessive about the way people react to Jesus. Wherever he appears, he is "creating frenzy" (ibid., p. 26); he attracts "misfits" "not one of [...whom] was normal" (ibid., p. 9): "fools, twitchers, malcontents, stammerers, all of them hysterical" (ibid., p. 66). The crowd at the wedding in Cana is driven by an insatiable hunger or desire. When Lazarus is raised, time is suspended, and life is held in (ibid., p. 30). After the resurrection of Lazarus, the usual gravity of existence is replaced by an unnerving "levity", pointless movement and "a strange atmosphere" (ibid., p. 36).

In her description of the beginning of Christianity, Mary emphasizes that which exceeds reason and fails to fit the socially accepted standards of behaviour, i.e. the characteristic 
elements of Gothic romance-like madness, excitement/excitability and desire. She also repeatedly returns to the problem of what lies outside language - to silence, the incapability of speech, the secret and the unspeakable. Thus, the resurrected Lazarus never speaks but howls and whimpers, carrying the secret of what he saw in death "as the body carries its own dark share of blood and sinew" (ibid., p. 46), i.e., in a non-discursive manner. Once a unique human being, miraculously unmarked by darkness and fear, he is now in a death-like state - "a glow of death around him" (ibid., p. 49), his beauty and radiance transformed into an uncanny embodiment of both terrifying and fascinating emptiness, his return to the living marked with a complete silence in the animal and human world.

This sense of the Gothic sublime - of glimpsing into the abyss for which there is no adequate representation - reaches its climax with Mary's traumatic experience of witnessing Jesus's crucifixion. Described in the novel as "the fierce catastrophe" (ibid., p. 8) and "the unspeakable image" (ibid., p. 59), the crucifixion keeps haunting Mary, who feels shame and guilt at the memory of having escaped from Golgotha before Jesus died. As she puts it, had she done anything instead of running away, she "would not have to go over and over it now" (ibid., p. 77). As it is, Mary cannot but remember various details which she observed on that hill, details which were "a distraction from what was really happening" (ibid., p. 73), and which mark the limit of representation. She notices a hurting shoe, a cloud, other crosses keeling, games played and fires lit, all of which yield easily to mimetic representation. Most importantly, she describes a man who gave live rabbits to a huge bird of prey kept in a cage. The bird did not eat any of the rabbits, but maimed them, plucking out their eyes and opening their underbellies. The horror of the scene, its pointless cruelty played out at one remove from the human world, among animals, is a circumlocutory way of representing her own traumatic experience, which remains something "unimaginable" (ibid., p. 86) and inassimilable into realistic representation. As a detailed yet meaningless image of an excruciatingly slow and painful death (it "made no sense" [ibid., p. 6]), the scene at the same time periphrastically reproduces the trauma of Jesus's death - his writhing body, the spurts of blood, the weakening moans - and manifests the impossibility of making it cohere with a rational picture of the world.

Admittedly, Mary's gothicized version of Jesus's life and death keeps circling around the incomprehensible, traumatic core of the crucifixion and death, which it often relates to the metaphor of darkness. The man with the bird and rabbits is "almost smiling with dark delight" (ibid., p. 7); there is "dark brutality" (ibid., p. 79) about Marcus, Mary's adoptive cousin and childhood companion, who works for the Jewish authorities and who controls the network of spies and informers rounding up Jesus' followers; the resurrected Lazarus is marked with 
darkness from which he used to be free; when rejected by her frightened kin, Mary understands that what was rising against Jesus was "something ferocious and exact, something dark and evil beyond anyone's comprehension" (ibid., p. 63). It is darkness which characterizes the actions of those who decide upon Jesus's crucifixion, and it is darkness which their actions produce and which Mary repeatedly links with "menace” (ibid., p. 14), "poison” (ibid., p. 13), cruelty and hunger (ibid., p. 69). The gothic darkness lodged at the centre of traumatic experience is a sublime image of desire, violence, evil, cruelty and death. But also, because it is compared to a contagion (ibid.) which spreads and infects everybody - including Mary herself, who now has "something in her heart that pumped darkness" (ibid., p. 12) - darkness epitomizes spillage and excess. In her gothicized romance, Mary tries to represent some unnameable phenomenon - a horrifying corruption, an inhuman malignity - emblematizing it with the metaphor of contagious darkness.

What transpires in Mary's dark romance is the observation that there is neither salvation nor release from the darkness and its contagion. In the scene of the escape from Golgotha, loosely evocative of some gothic trappings associated with the distressed heroine's flight from a tyrannical male figure, Mary wants to save herself from Marcus (who had pretended to be protective and tries to lure her into a trap, have her arrested and killed) and from the strangler (a hired murderer, always watching her). Although she finds shelter in Ephesus, where she is protected by Jesus' followers who come to collect and write down her memories, she does not feel safe. Importantly, it is not only that "the cursed shadow of what had happened would [...not] lift" (ibid., p.12). What troubles her is the darkness she discerns in the male disciples who regularly visit her in her new place. "Their eyes hooded and something dark appearing in their faces" (ibid., p. 100), they become carbon copies of Marcus and the strangler. They are similarly "deliberate, [...] exact [...], dedicated" (ibid., p. 102). Like the cruel, powerful men in Jerusalem, who dehumanized everybody around, the disciples change women into "hunched and obedient animals" (ibid., p. 67). The "enormity of their ambition" (ibid., p. 101) is not unlike the uncanny craving of the bird of prey, which "suffered from a deep hunger that even the live flesh of writhing rabbits could not satisfy" (ibid., p. 6). Infected with a traumatizing darkness, the disciples will carry the contagion, passing it on - through their new religion - to future generations. Their triumph predicted by Mary (ibid., p. 103) will be no positive reconstitution of a traumatized group identity, no restoration of a lost sense of unity. Rather, it will be a repetition, a re-enactment of the traumatic event - a monstrous rehearsing of cold cruelty and dark brutality. 
Mary's subversive romance is meant as a counterbalance to the euphoric romance constructed by the male disciples. Jesus's followers believe the crucifixion to be something "planned, part of a great deliverance that would take place in the world" (ibid., p. 67). Out of the "confusion, [...] strange memories" (ibid., p. 80), the randomness and uncertainty of the events, they weave "sharp simple patterns [...] of what happened" (ibid., p. 4). Like Mary, they acknowledge the "great disturbance in the world" (ibid., p. 56) at the time of Jesus's ministry, but unlike Mary, they believe that the disequilibrium has been mended and that balance in the world is restored. They treat Mary's dream of Jesus coming back to life as a true event, and make it the apex of their newly written scripture. Insofar as they construct a story "where what happened in [...] dreams took on more flesh, had more substance" than real lives (ibid., p. 93), their narrative takes on features of romance as a wish-fulfilment dream (cf. Frye 1957, p. 186). When they claim that Jesus's death "has freed mankind from darkness and sin" (Tóibín, 2012, p. 100, my emphasis), they both acknowledge their anxiety of reality and of death, and reassure themselves of the deliverance. By thinking of darkness as something manageable (ibid., pp. 8283), the disciples avoid the disquieting effect of the sublime in Mary's traumatic account, and believe themselves to be able to arrive at the point of full cognition and healing. From Mary's perspective, however, her son's allegedly redemptive death not only did not eliminate darkness from the world but also spread its poisoning, traumatizing quality into those very people who propagate the story of its overcoming. Mary's reliance on the gothic, a convention often employed as a "warning of dangers of social and moral transgressions" (Botting, 1996, p. 7), is a way of bringing into the light the suppressed, darker, trauma-inducing side of the Christian religion (or religions in general), an exercise in Vitoux's ironic romance which exposes evil in a disenchanted, world-weary way.

\section{Conclusion}

The coexistence of two types of romance in The Good Man Jesus and the Scoundrel Christ and The Testament of Mary - euphoric romance and either romance of dilation or Gothic romance - foregrounds the fact that the Christian Bible (to return to Carr's observation) contains both a narrative that integrates the trauma of the crucifixion into the larger picture of Christian identity and memory, and elements which signal the incompleteness, if not impossibility, of such an integration. Moreover, the prominence of subversive/dilatory romance in the two novels and the centrality of scripture-transmitted evil draw attention to the fact that for all the uplifting, anxiety-removing, meaning-endowing qualities of Christian scripture, it also contains more problematic elements that cannot be subsumed by the healing, sacred-romance-like story. 
Remembering her experience of the Torah readings on the Sabbath day, Mary says that on the one hand, there was a mixture of peace and comfort built by the narratives, and, on the other hand, there was "a sense of something else [...she] could not name that had lurked between the words of the book as though in waiting like hunters, or trappers" (Tóibín, 2012, p. 18). The biblical rewritings discussed here emphasize this duality of the Christian Bible - its traumacoping or trauma-healing potential, here mediated by the trappings of the euphoric romance, as well as its hard-to-name, traumatizing, dark quality, rendered in the novels through entropic romance.

Moreover, the self-reflexive, metafictional dimension of the two novels urges the reader to look closely at the way euphoric romance easily becomes an ideological instrument employed by power-craving people to achieve their dark aims. Both Pullman and Tóibín point out that the comforting sacred romance of redemption all too often changes into a traumaperpetrating device. As Pullman's Jesus observes about the effects of his twin brother's idea of the Church and its scripture, "as soon as men who believe they're doing God's will get hold of power, [...] the devil enters into them" (Pullman, 2010, p. 197). They will use the scriptural narrative of the redemption, allegedly deposited solely in their hands, to terrorize, brutalize and traumatize both believers and unbelievers. Thus, the biblical rewritings tell us that the U-shaped romance of salvation all too easily tips over into entropic romance, and becomes a secondorder, re-appropriated narrative underlain by transgression, violence and cruelty.

Reflection on the ideological and potentially traumatizing effects of the manipulative use of the narrative of crisis and redemption is especially pertinent today, at the time of the "new visibility of religion" (Ward and Hoeltzl 2008) and the "de-privatization" of religion (Casanova 1994). With traditional religions re-acquiring a public role and thrusting themselves into the arena of moral and political contestation, and with different religious elements deployed in new ways across cultural discourses, the recognition that a religious (Christian) romance of redemption can be appropriated to dominate rather than to emancipate anxiety-ridden, comfortseeking people - though not new - may be quite valuable. To acknowledge that "Christian institutionalisation of trauma has sometimes contributed to more suffering" (Carr, 2013, p. 246) is not to claim that the narrative of salvation should be abandoned but to understand that the obverse of euphoric romance is often a dark story of unredeemed and perhaps inexpressible guilt, shame and terror.

\section{Endnotes:}


${ }^{i}$ As Carr argues, "early Jesus followers found themselves focusing on Hebrew scriptures formed in the midst of earlier Jewish traumas" (Carr, 2014, p. 164) of the Assyrian conquest and the Babylonian exile. ii The institutionalized trauma, according to Carr, has "contributed to its centuries-long antipathy toward Judaism, an antipathy that has led to the deaths and suffering of millions of Jews. And there is certainly more that could be said on this topic" (2014, p. 246). Carr mentions other cases of "Christian crucifixion fixation" (2014, p. 242), like the Church encouraging Christians to seek martyrdom and enact the trauma of Jesus's death, and subtle contemporary ways of embracing otherwise avoidable suffering related to domestic abuse.

iii For both Carr and Frye, the Bible frames disastrous events within a larger, optimistic structure, in which suffering is redeemed either by the deliverance offered by a (divine) hero (Frye), or by integration into master narratives constructed by/for resilient biblical communities (Carr).

${ }^{\text {iv }}$ In this paper, I understand romance as a mode (i.e., a trans-generic phenomenon, a set of flexible strategies) rather than as a genre (i.e., a more narrowly defined type of composition, displaying a number of common traits).

${ }^{v}$ Attempts at reading Acts through the prism of Greek romance have been criticized for over-stretching the similarity between the two and neglecting the fact that Acts does not display some of the characteristic features of ancient romance. Witherington points out that the motif of two parties (lovers) separated for a long time (and then reunited) is absent in Acts, as are the motifs of sex and marital relationship, pirates and bandits, a happy ending and an overall entertainment purpose (rather than just entertaining introjections like Acts 20:7-12). Moreover, unlike Greek romance, Acts is full of long speeches, shifts from one major figure to another, and contains a real sense of tragedy. Also, Witherington criticizes Pervo for diluting the difference between canonical Acts and apocryphal acts (Acts of Thecla, for example, are much closer - both thematically and formally - to Greek romance).

${ }^{v i}$ Consequently, although concerned with divine heroes, who are superior in kind to mortals and transcendent in relation to the human world, the myths show gods/God acting within the time and space of mortal life and occasionally benefitting from the suspension of natural laws, i.e. acting in a manner of the romance hero. Vitoux treats both the Old and the New Testament ("the Judeo-Christian myth" [2007, p. 393]) as examples of romance in the mythic mode, and points out that both Jehovah and the Christian God intervene in the affairs of the human world and reveal themselves through their actions in the mortal sphere. As he puts it, "the bulk of what we call 'the ancient myth' belongs to the literary category of romance [...]" (Vitoux 2007, p. 393).

vii To the extent that Jesus and Christ are nearly identical in physical appearance yet starkly different in every other respect, the motif can be seen as a framing metaphor crucial to explore and problematize the affinity and divergence between various contrasts and paired overlaps on which the novel focuses. Thus, apart from pointing out the problem of two types of romance, the motif can be seen as representing a contrast between the commendable (if idealistic and naïve) historical core of Christianity (represented by Jesus) and the despicably manipulative, power-oriented institutionalization of Jesus's teaching (represented by Christ and the Stranger).

viii The idea of Jesus's twin brother appears in the Coptic Gospel of Thomas, one of the non-canonical gospels belonging to the Nag Hammadi library. The gospel is a collection of sayings, which - as the opening avers - were presented by Jesus to Didymos Judas Thomas, whose name contains a double reference to "twin" ("Didymos" and "Thomas" both mean "twin" in Greek and Aramaic respectively). The introduction to the Gospel of Thomas has been sometimes read as referring to Jesus's twin brother, especially that "Judas" is another form of the name "James", a figure mentioned in Mark 6:3 and identified there as Jesus's brother.

ix Pullman draws heavily on the non-canonical The Infancy Gospel of Thomas, in which Jesus is presented as impulsive and mischievous and which recounts many miracles performed by him. Admittedly, apocryphal gospels are much more interested in the marvellous than canonical gospels. Since apocrypha rely on a dychotomized vision of the world and on miracles and are therefore very close to the romance genre (Josipovici 1990, p.222), the prominence of the non-canonical gospels in Pullman's novel is what can be seen as contributing to the romance character of the rewriting.

x "I find myself choking with happiness, or maybe sorrow" (Pullman 2010, p.193); "my mouth will be full of ash and my throat will burn with gall" (Pullman 2010, p.196); "my whole heart and mind and body revolted against that" (Pullman 2010, p.197); "I love every grain of sand and blade of grass and drop of blood" (Pullman 2010, p.200). 


\section{Works cited:}

Botting, F., 1996. Gothic. London \& New York: Routledge.

Carr, D.M., 2014. Holy Resilience. The Bible's Traumatic Origins. New Haven and London: Yale UP.

Caruth, C., 1991. Introduction. In American Imago 48.1, pp. 1-12.

Casanova, J., 1994. Public Religions in the Modern World. Chicago: University of Chicago Press.

Elam, D., 1992. Romancing the Postmodern. London: Routledge.

Frye, N., 1957. Anatomy of Criticism: Four Essays. Princeton, N.J.: Princeton UP.

Ganteau, J.-M., Onega, S., 2013. Introduction. Traumatic Realism and Romance in Contemporary British Narrative. In: Ganteau, J-M., Onega, S. (eds.). Trauma and Romance in Contemporary British Literature. London: Routledge, pp. 1-14.

Heng, G., 2003. Empire of Magic. Medieval Romance and the Politics of Cultural Fantasy. New York: Columbia UP.

Josipovici, G., 1990. The Book of God: A Response to the Bible. Yale: Yale UP.

Loveday, A. 2007. Acts in its Ancient Literary Context. London \& New York: T\&T Clark International.

Mączyńska, M., 2015. The Gospel According to the Novelist. Religious Scripture and Contemporary Fiction. London \& New York: Bloomsbury Academic.

Parker, P. A., 1979. Inescapable Romance: Studies in the Poetics of a Mode. Princeton: Princeton UP.

Pullman, P., 2010. The Good Man Jesus and the Scoundrel Christ. Edinburgh: Canongate.

Tóibín, C., 2012. The Testament of Mary. London: Viking.

Vitoux, P., 2007. The Mode of Romance Revisited. In: Texas Studies in Literature and Language, Winter 49.4, pp. 387-410.

Ward, G., Hoelzl, M., 2008. Introduction. In: Ward, G., Hoelzl, M. (eds.). The New Visibility of Religion: Studies in Religion and Cultural Hermeneutics. London \& New York: Continuum, pp. 1-11.

Witherington, B., III. 1998. The Acts of the Apostles. A Socio-Rhetorical Commentary. Grand Rapids, Michigan, Cambridge, UK: Wm. B. Eerdmans Publishing.

Ewa Rychter

The Angelus Silesius University of Applied Sciences in Wałbrzych

ul. Zamkowa 4

58-300 Walbrzych

Poland

erychter@pwsz.com.pl 